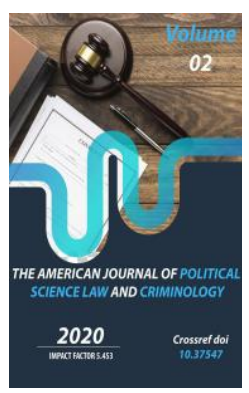

\title{
Implementation Of Corruption Prevention Measures In The Private Sector Of Uzbekistan
}

\author{
Bakhodir Ismailov \\ Doctor Of Law The Academy Of The General Prosecutor's Office Of The Republic Of Uzbekistan
}

Copyright: Original content from this work may be used under the terms of the creative commons attributes 4.0 licence.

\section{ABSTRACT}

The article examines the experience of Uzbekistan in preventing corruption in the private sector. It is determined that the negative factors of the spread of corruption among companies leads to a decrease in the competitiveness of the national economy, the quality of public administration, undermines the foundations of free competition, creates threats to the political stability and security of the country.

With the spread of corruption, the business climate and the quality of corporate governance deteriorate, the reputation of companies is undermined, and their investment attractiveness decreases.

In the markets of goods, works, services, negative selection is taking place, monopoly and protectionism are increasing. It was revealed that corruption in the private sector devalues democratic values, contributes to the spread of legal nihilism, permissiveness, money-grubbing, impunity, etc., causing significant harm to the interests of both society and the state, and the rights of citizens.

The thesis is substantiated that the most effective means of preventing corruption in the private sector is the introduction of anti-corruption compliance systems and the corresponding methods of their certification into its subjects. Based on the methods of a comparative study, measures have been identified to introduce anti-corruption compliance in business structures, as well as business entities with state participation.

It is determined that international universal, regional and special standards (UN, OECD, GRECO, ISO, etc.) have a significant impact on the development of national legislation and practice of law enforcement in this area. The thesis about the need to improve the legal foundations of the anticorruption compliance system, the need to introduce institutions of responsibility of legal entities in Uzbekistan, prevent illegal lobbying activities, etc. 


\section{KEYWORDS}

Private sector, corruption, anti-corruption compliance control system, lobbying, liability of legal entities, illegal lobbying

\section{INTRODUCTION}

Nowadays, shadow economy and corruption are one of the main global problems that affect further development of both international community and each country separately. These negative factors undermine economic foundations of countries, distort market mechanisms, adversely affect on investment attractiveness of a country, discredit public policy, complicate business environment, undermine competitiveness of national economies.

Besides, corruption weakens democracy institutions and the rule of law, leads to degradation of public administration and human rights violations, worsens quality of life, significantly increases cost of production, promotes growth of organized crime, terrorism and other threats to international security.

Corruption in the private sector is especially dangerous. According to experts of Deloitte, $30 \%$ of total corruption offenses in the world are committed within private sector. On average, each business entity loses $5 \%$ of its annual revenue due to corruption crimes, the average loss under one scheme are about $\$ 250,000$, the average loss incurred due to power abuse of owners/top management are estimated at $\$ 573,000$, committed by management - $\$ 180,000$ and committed by employees - \$60,000 [1].

Corruption scandals of the 1970 s and 2000 s years involving top managers of such large foreign companies as BAE Systems, Great
Britain (2006, $£ 2$ billion bribes), Hyundai Motor, Korea (2007, \$130 million), Baker Hughes Inc (2007, \$219 million), Siemens, Germany (2008 \$1.4 billion), Daimler, Germany (2010, €5 million), Panalpina World Transport, USA (2010, \$49 million), Petrobras, Brazil (2014, \$3,8 billion), Hewlett - Packard, USA (2011, \$5 million), Walmart, USA (2012, \$138 million), TeliaSonera, Vimpelcom and MTS Sweden, Russia, (2012-2015, TeliaSonera \$360 million), MTS, \$380 million, VimpelCom \$150 million), Hanlong Group, China (2015, 3.1 billion yuan), Samsung Group, Korea (2017, 43.3 billion won ), Odebrecht, Brazil (2016, \$800 million), Volkswagen, the FRG (2019, €750 thousand) etc. contributed to enhancement of measures counteracting corruption in the private sector [2].

Analysis of negative impact of corruption among companies shows the following outcomes:

sharp reduction of competitiveness of national economy, quality of public administration of the economy, formation of threats to political stability and security, as well as foundations of free competition;

deterioration of business climate, quality of corporate governance, reputation of companies and their investment attractiveness, as well as occurrence of negative selection in markets goods', works, services; increase of monopoly and protectionism; 
devaluation of democratic values, cultivation of permissiveness, greed, impunity etc., as well as substantial harm to interests of society, state and the rights of citizens;

growth of white-collar and organized crime, risk of money laundering and withdrawal of assets abroad.

Post-Soviet countries' representatives of criminal law science often stated that [1] criminogenic factors that determine corruption most often as follows:

a) Weakness of political power;

b) Contradictions and belatedness of legislative decisions;

c) Uncertainty of legal norms;

d) Closed or non-transparent law enforcement procedures;

e) Lack of public control over distribution and use of budgetary funds and external borrowings;

f) Irresponsibility of authorities failing to ensure inevitability of punishment for representatives of highest officials, big entrepreneurs and leaders of organized crime;

g) Lack of proper control over civil servants' sources of income;

h) Existence of uncontrolled shadow economy that is used to finance corrupt officials;

i) Flawed rules for selection of personnel in for public service, ensuring low level of culture, legal awareness and professionalism of officials;

j) Unsatisfactory wages, stimulating a medieval institution of "feeding" (officials replenish their low official income with bribes from the population);

k) Unbalanced economic relations, high taxes and rising unemployment;

I) Excessive scale of public administration;[2]

m) Criminalization of power at all its levels; n) Unfair differentiation of the population by property;

o) Education of legal nihilism in the population by various institutions of state power in connection with obvious miscalculations in domestic policy of a country;

p) Omissions in shaping the outlook of population, that lead to change in value orientations from striving for the wellbeing of society and state to personal enrichment, including by illegal methods and institutions of power. [3]

Criminology and forensics scientists identify factors that "provoke" corruption, including:

a) Inconsistency of legislative process with socio-economic and political situation in the country;

b) Unsatisfactory work of law enforcement and regulatory agencies;

c) Distorted forms of socio-economic transformations leading to more acute property differentiation of the population;

d) Practice of bribery and selfish abuses of officials turned into a legal custom;

e) Impunity for corrupt officials in the highest authorities;

f) Decrease of population's belief in the triumph of social justice principles and spread of legal nihilism[4].

At the present stage of large-scale reforms carried out in Uzbekistan, the problem of strengthening legal, institutional and organizational measures to combat corruption in the private sector acquires particular relevance.

Today, 440,879 enterprises are registered in Uzbekistan, including 245,127 limited liability companies, 92,585 - private enterprises, 679 joint stock companies, 32,834 - family enterprises, 2,964 - unitary enterprises, 3,900 other forms [3]. At the same time, the number 
of enterprises and organizations operating in our country was: trade organizations - 108,576, other types - 105,034, industry - 73,655, construction - 37,516, agriculture, forestry and fishing - 31,438, accommodation and food services $-26,848$, transportation and storage 15,765, information and communication 8,277 , health and social services - 8,221. Number of economic entities included in the State Register of Natural Monopolies is 135 units.

Analysis of trends in corruption crime situation shows that corruption has an extremely negative effect on the processes of large-scale transformations being carried out in Uzbekistan. Unfortunately, despite the measures taken, private sector accounts for a significant part of the detected corruption crimes (about 35-40\%) committed by officials [4].

So, in 20172076 criminal cases were initiated against 3,013 officials, in 2018 this figure composed 1,469 cases against 2,066 persons, as well as 994 cases were initiated against 1,520 persons in 2019, and 327 criminal cases were initiated against 459 persons in six months of 2020.

As a result of corruption offenses interests of both country and citizens undergone significant economic and political damage. For example, the damage in 2017 was 142 billion soums, in 2018 - 662 million soums, in 2018 - 559 billion 174 million soums, in 2019 - \$ 1 trillion 853 billion soums, and in the first 6 months of 2020 - 172 billion 260 million soums [5].

These figures show the necessity of urgent organizational and legal measures aimed at preventing corruption in private sector. In this regard, it is extremely important to take into account the experience of foreign states and international organizations in this area.
In order to prevent corruption in the private sector, a number of foreign countries introduced an effective mechanism called anticorruption compliance designed to identify and analyze corruption-dangerous spheres of activity, assess and manage legal and financial risks in the event of corruption, ensure comprehensive protection of business from various legal, tax, economic, reputation, sanction and other threats [6]. Anti-corruption compliance system was first introduced in the US (1906).

In the result of corruption scandals in private companies in the 1960-70s the adoption "Foreign Corrupt Practices Act" (FCPA) of the US in 1977, that established strict control over accounting and financial records, as well as rules of relationships with government officials [7]. With the adoption of Sarbanes-Oxley Act (SOX) in 2002, financial reporting requirements were significantly tightened, establishing obligation of companies' adopting codes corporate conduct and to report to American regulator. Priority areas of compliance were:

Ensuring corruption countering in any of its types (bribery, commercial bribery, power abuse);

Unconditional observance of current legislation, as well as internal regulatory and administrative documents of organization groups;

Development and implementation of measures aimed at reducing compliance risks and continuous improvement of internal control systems in areas of activity with high compliance risks;

Ensuring accordance to compliance principles by counterparties in the implementation of contractual relations of the corporation;

Preference for cooperation with business partners adhering to the same values; 
Ensuring the possibility of identifying and resolving conflicts of interest, including potential ones;

Providing employees and third parties with the opportunity to confidentially and, if desired, anonymously report possible violations of compliance standards via hotline or by e-mail;

Inevitability of disciplinary measures in case of violation of compliance standards by employees;

Implementation of constant monitoring of compliance system in the corporation [8].

In connection with financial scandals that took place in the United States in 2008, the Dodd Frank Act was adopted in 2010, that set a number of additional anti-corruption measures to ensure transparency in financial markets' operations.

Currently, almost all foreign corporations listed on the US financial market have implemented compliance services. In 2010, the UK AntiCorruption Act was adopted in order to combat corruption both within the country and abroad [9]. In analogy with the USA and Great Britain, a number of industrialized countries (Germany, France, Japan, the Republic of Korea, etc.) adopted in 2015-2020 legislative acts aimed at combating corruption in the private sector.

International standards in this area also had a significant impact on the development of legislation of many states. In particular, as a result of active US position The OECD AntiBribery Convention (officially Convention on Combating Bribery of Foreign Public Officials in International Business Transactions) adopted in 1997. [10].

To help governments and companies develop and implement codes of conduct and anticorruption policies, the OECD has published a number of guidelines and recommendations. The most significant of these are: Recommendations on Bribery and Supported Export Credit (2006) [11], OECD Principles on Integrity in Public Procurement (2008) [12], Recommendation on Further Combating Bribery of Foreign Officials persons in international business transactions (2009) [13], Recommendation on Taxation in Relation to Countering Bribery of Foreign Officials in International Business Transactions (2009) [14], Guidelines for Good Practice in Internal Control, Ethics and Compliance (2010) [15], OECD Guidelines for Multinational Enterprises (2011) [16], etc.

In particular, the Good Practice Guidance on Internal Control, Ethics and Compliance summarizes best practices of companies. The best practices include: participation of top management of companies in the prevention of bribery; a clearly defined public position of the company regarding the inadmissibility of bribery of foreign officials; establishing the obligation to comply with anti-corruption standards at all levels of the company; overseeing compliance with ethics and compliance programs, including the right of responsible employees to inform the audit committee of the board of directors of identified violations; extending the ethics and compliance program to all branches and companies over which the company exercises effective control; application of the provisions of anti-corruption policy in relations with third parties, including intermediaries and contractual partners.

The guide notes important role of business and professional associations. They can help disseminate information about new anticorruption legislation, international and regional initiatives, advise companies on the implementation of anti-corruption procedures and train employees. 
Financial Action Task Force on Money Laundering (FATF) plays a certain role in the development of international cooperation in combating corruption. Organization's standards for prevention of terrorist financing and the proliferation of weapons of mass destruction dated 16.02.2012, are important for the development of anti-corruption legislation and anti-corruption compliance control in companies. This concerns Recommendations 1 (assessment of risk level and application of riskbased approach), 10 (identification and study of clients), 11 (storage of documents), 19 (countries with a high level of risk) [17] .

Recommendation 12 regarding work with foreign and national PEPs should be considered when developing anti-corruption policies of companies.

In order to eradicate corruption in all spheres of society, Uzbekistan is taking appropriate legal, institutional and organizational measures. Adopted at the initiative of the President of Uzbekistan, the Law "On Combating Corruption" dated January, 3, 2017, regulated following measures to prevent corruption both in public administration and in the fields of socio-economic development and entrepreneurship:

Elimination of administrative and bureaucratic barriers, simplification and improvement of registration, permitting and licensing procedures;

Optimization of supervisory functions of state bodies, improvement the inspection system of business entities, prevention of unlawful interference in their activities;

Widespread introduction of remote forms of relationships between government bodies and business entities;

Creating equal conditions for doing business and preventing unfair competition;
Introduction of effective legal mechanisms for public procurement, ensuring publicity, transparency and maintaining a competitive environment in public procurement;

Creation of fair conditions and equal opportunities for population in education, health care, social security, public services and other areas of social and economic development, prevention of corruption offenses;

Introduction of effective anti-corruption mechanisms in non-governmental organizations etc.

In order to improve efficiency of anticorruption system, create most favorable business climate, promote positive image of our country in the international arena, the State Anti-Corruption Program for 2019-2020 was approved by the Decree of the President of the Republic of Uzbekistan "On measures to further improve the anti-corruption system in the Republic of Uzbekistan" No. UP-5729 dated 05/27/2019. It provides such measures for strengthening anti-corruption in state-shared organizations as introducing anti-corruption "compliance control" system and monitoring its effectiveness, establishing certification procedure for the appropriate anti-corruption standard (ISO 37001). These measures also include active implementation of special anticorruption measures in the private sector by strengthening measures and procedures of internal control, ensuring strict ethical rules when participating in public procurement, encouraging collective anti-corruption actions of business society.

Republican Council for collaboration with international ratings and indices was established in order to improve investment attractiveness and strengthen the image of our country in the international arena, as well as to introduce new mechanisms in state bodies and 
organizations for dealing with ratings and indices, (the Decree of the President of the Republic of Uzbekistan "On improving the position of the Republic of Uzbekistan in international ratings and indices, as well as introducing a new mechanism in government agencies and organizations for systematic collaboration with them" No. UP-6003 dated 02.06.2020).

Protocol of the Republican Council No. 2 dated June 13, 2020, approved Program of measures to improve the position of the Republic of Uzbekistan in the socio-economic and politicallegal international ratings and indices, providing for implementation of 227 specific measures, including taking urgent measures to strengthen departmental anti-corruption systems, introduction of anti-trust and anticorruption compliance, strengthen responsibility of officials in the field of anticorruption etc.

As the next logical stage of reforms, The Presidential Decree "On Additional Measures to Improve the Anti-Corruption System in the Republic of Uzbekistan" was adopted (UP-6013 dated June 29, 2020).

In accordance with the Decree, the AntiCorruption Agency of the Republic of Uzbekistan and National Council for combating corruption were established.

The Agency is a specially authorized state body responsible for the formation and implementation of state policy in the field of preventing and combating corruption.

The agency obeys to the President and reports to the chambers of the Oliy Majlis.

The decree defines the main tasks and activities of the Agency. In particular, the Agency provides a systematic analysis of the state of corruption in the country.
The Agency conducts a comprehensive analysis of the results of the investigation of corruption crimes, primarily harmful to the national interests and international authority of Uzbekistan.

The agency is also granted a number of the following rights:

Request, receive and research materials related to budget expenditures, implementation of state assets, public procurement, implementation of investment projects and implementation of government programs;

Consider appeals of individuals and legal entities on corruption issues and take measures to restore their violated rights and protect their legitimate interests;

Conduct administrative investigations of corruption offenses;

To make binding orders on suspension of execution or annulment of decisions of executive authorities, economic management bodies and their officials if signs of corruption are detected in them.

Main directions of the Agency were defined as follows:

Organization of implementation and effective functioning of internal anti-corruption control system ("compliance control") in government and economic management bodies, state enterprises;

Carrying out anti-corruption monitoring and compiling a rating in this area on the basis of modern methods and ICTs;

In order to accomplish these tasks, the Agency and other interested departments were instructed to take measures for a phased implementation, s well as with involvement of funds from international organizations, in 
2020-2021 in all government and economic management bodies of the internal anticorruption control system ("compliance control").

Adoption of roadmaps is designed to ensure the full implementation of compliance systems , as well as modern information technologies, minimize the "human factor" in the exercise of discretionary powers by authorized officials, create zero tolerance among responsible officials for any facts of antisocial behavior, minimize the risks of corruption, form effective mechanisms of anti-corruption control, etc.

Roadmaps provide for the implementation of about 40 specific measures to introduce departmental anti-corruption compliance systems, including:

Analysis of existing problems, and taking measures to minimize them;

Determination of corruption risks and composing the list of officials exposed to high corruption risks;

Elaboration of departmental anti-corruption strategies and creating units of compliance;

Improvement of conflict-of-interest prevention mechanisms;

Strengthening measures to protect individuals reporting corruption and unlawful behavior;

Establishing systems of internship of skilled workers in the field of combating corruption, developing integrity and honesty skills, raising awareness of consumers;

Taking measures to further develop internal anti-corruption control, targeted interaction with civil society institutions, mass media, civil activists etc.

In view of step-by-step implementation of anticorruption compliance systems, extensive interaction is being carried out with most authoritative international organizations such as KPMG, CERT etc.

In conclusion, we should note the actuality of the following targeted measures:

1. Development and adoption of Resolution of the Cabinet of Ministers "On approval of the Model Regulation "On AntiCorruption Compliance service in stateowned business entities" which regulate the fundamental regulatory requirements for the goals, objectives and main areas of Anticorruption Compliance service, its legal status and the circle powers of compliance officers.

It should be noted that in international practice, legal status of anti-corruption compliance service may be specified either in specific laws ("Slovenian state holding Act" dated 18.08.2014 [18], Brazilian Law "On a clean company" of August 1, 2013 [19]), or in indirect anti-corruption laws. In most cases, Anti-Corruption compliance is understood as a managerial process enabling the following:

Determination of applicable legal regulations;

Assessment of corruption risks;

Formation of local legal and ethical norms aimed at preventing involvement of the company and its employees in committing corruption offenses;

Company's daily activities to manage risks and ensure compliance with these legal and ethical standards.

2. In order to create a system of training, retraining and advanced training of Anticorruption Compliance services personnel, we propose to define the Chamber of Commerce of the Republic of Uzbekistan as the authorized body in the field of training compliance professionals, $s$ well as development of special 
"Anticorruption Compliance" courses. At the same time, it should be noted that in foreign practice, various models of training anti-corruption compliance officers are used (retraining of employees of legal and personnel services, internal control and security units, targeted training of anticorruption compliance officers in specialized national and international educational institutions).

3. Bringing the criminal legislation of the Republic of Uzbekistan in line with the norms of the UN Convention against Corruption (Article 26) by introduction of the institution of legal entities criminal liability. It should be borne in mind that in the legal doctrine of common law countries (USA, UK, Canada, etc.), the institution of legal entities liability, including for corruption offenses has been in effect for more than two hundred years [20].

Currently, criminal liability of legal entities exists in the legislation of more than 50 countries. In particular, Australia, England, Belgium, Hungary (since 2001), Denmark, Israel, Ireland, Iceland (since 1998), Canada, China (since 1997), the Netherlands (since 1976), Norway ( since 1991), Poland (since 2002), Romania (since 2004), Slovenia (since 1999), the USA, Finland (since 1995), France (since 1992), Switzerland ( since 2003) and other countries, including the former USSR.

A variety of criminal sanctions can be applied to corporations including liquidation, restriction of rights, confiscation of property, fines, compensation for damage, announcement of the judgment, ban on public procurement participation, probation etc.

4. Suppression of illegal actions in business relations with government agencies, as well as of illegal lobbyist activity.
There has been an increase in the number of international recommendations and standards in the field of legal regulation of lobbying activities in recent years. In particular, the OECD member countries adopted "10 principles of transparency and integrity in lobbying activities" in 2010 [21]. As of 2020, special laws on lobbying at the national level have been adopted in more than 20 countries Georgia (1998), Brazil (1985), Lithuania (2000), Israel (2008), Austria (2012), Ireland (2015), Poland (2005), Slovenia (2010), Montenegro (2014) and others.

\section{Developing anticorruption initiatives of} business entities is also an actual direction of counteraction of corruption in the private sector. These initiatives are intended for self-regulation on the basis of national legislation and key anti-corruption international documents. An example is the International Chamber of Commerce (ICC) 1977Anti-Corruption Rules: corporate social responsibility and anti-corruption, aimed to prevent negative exposure of corruption on contractual relations.

Currently, about 40 countries (Ukraine, Georgia, Azerbaijan, Moldova, Kyrgyzstan etc.) encourage cooperation in anti-corruption practices in the form of charters, codes of ethics conduct business and others.

As an example, we can cite the Charter of Entrepreneurs of Kazakhstan on Combating Corruption, the Anti-Corruption Charter of Russian Business etc.

In a number of states, Chambers of Commerce, Business Ombudsmen, Producers' Associations, consumer protection societies, mass media etc. are involved in combating corruption in the private sector.

Summing up, at the present stage of anticorruption reforms carried out in Uzbekistan, it 
is very relevant to study and, more importantly, to actively introduce anti-corruption measures into the national law enforcement practice, including introduction of unified anticorruption compliance systems, certification in accordance with anti-corruption management system standards, etc.

\section{REFERENCES}

1. Hayat S. Secret World of International Fraud and the Network of Global Corruption. - M.: Pretekst, 2019 - P. 156.

2. https://www.rbc.ru/photoreport/16/01/ 2017/587caeb39a7947b1d2bb842c .

3. As of 1st quarter of 2020. "Socioeconomic situation of the Republic of Uzbekistan // https://stat.uz/uz/

4. Data from the Telegram channel of the General Prosecutor's Office of the Republic of Uzbekistan.

5. Press service of the Prosecutor General of the Republic of Uzbekistan http://prokuratura.uz/\#/t_news?id=280

6. Bonneau JL Combatting Foregn Bribery: Legislative Reform in the United Kingdom and Prospects for Increased Global Enforcement // Colum b ia Journal of Transnational Law. 2011. Vol. 49. N 2.

7. Reuven S-Avi-Yonah. National Regulation of Multinational Enterprises: An Essay on Comity, Exterritoriality and Harmonization // Columbia Journal of Transnational Law. 2003.

8. Council of Europe, http ://assembly . coe . int .

9. Out of the Frying Pan. The UK's new Bribery Act will have a big impact on business worldwide. But corporates must not ignore their obligations under existing anti-money laundering laws //
International Financial Law Review. 2011. July / August. P. 44.

10. Convention on Combating Bribery of Foreign Public Officials in International Business Transactions and rela ted documents. www.oecd.org/daf/antibribery/ConvCombatBribery_ENG.pdf

11. OECD Council Recommendation on Bribery and Officially Supported Export Credits.

12. OECD Principles for Integrity in Public Procurement. / www . oecd . org / gov / ethics / 48994520. pdf

13. Recommendation of the Council for Further Combating Bribery of Foreign Public Officials in International Business Transactions. www.oecd.org/daf/antibribery/44176910.pdf

14. Recommendation on Tax Measures for Further Combating Bribery of Foreign Public Officials in International Business Transactions. // www.oecd.org /corruption/keyoecdanticorruptiondocuments.htm

15. Good Practice Guidance on Internal Controls, Ethics and Compliance. / http://www.oecd.org/daf/anti-

bribery/44884389.pdf

16. http :// mneguidelines . oecd . org/text / MNEGuidelinesRussian . pdf

17. Recommendation on Tax Measures for Further Combating Bribery of Foreign Public Officials in International Business Transactions/

www.oecd. org / corruption / keyoecdanti-

corruptiondocuments.htm

18. The FATF Guidance on Transparency and Beneficial Ownership. www.fatfgafi.org/media/fatf/documents/reports 
The American Journal of Political Science Law and Criminology (ISSN - 2693-0803)

Published: December 27, 2020 | Pages: 41-51

Doi: https://doi.org/10.37547/tajpslc/Volume02Issue12-07

/Guidance-transparency-beneficial-

ownership.pdf

19. Slovenian sovereign holding Act of 2014. www.slovenian.com.sl .

20. Law N 12846 , of August 1, 2013. // www.latini.com.br

21. The Supreme Court decision in the case of New York Cent\&H.R.R. vs. United States 212 U.S. 481, 29 S.Ct. 304,53 L. Ed. 613 (1909). 